\title{
HOLOGRAPHIC RECORDING IN PHOTOCHROME-CHALCOGENIDE COMPOSITES
}

\author{
A. Gerbreders ${ }^{\mathrm{a}, \mathrm{b}}$, J. Aleksejeva ${ }^{\mathrm{a}}$, A. Danilovs ${ }^{\mathrm{a}}$, and J. Teteris ${ }^{\mathrm{a}}$ \\ ${ }^{a}$ Institute of Solid State Physics, University of Latvia, Kengaraga 8, LV-1063 Riga, Latvia \\ E-mail: andrejmah@gmail.com \\ ${ }^{\mathrm{b}}$ Department of Physics, Daugavpils University, Parades 1, Daugavpils, LV-5401, Latvia
}

Received 26 August 2009; revised 17 February 2010; accepted 19 March 2010

\begin{abstract}
The method of preparation of thin triple composite films of organic polymer-chalcogenide-photochromes is described, and some features of photo induced changes of optical properties and holographic recording in this system are studied.

Films of composite were obtained from solutions of arsenic sulphide and organic polymers, such as "Disperbyk" (produced by BYK-Chemie $\mathrm{GmbH}$ ) and polyvinylacetate in organic solvents. The azobenzene DR-1 and spiropyran solutions were added in this mixture. The films were obtained by casting the material on glass or quartz substrate. The dry film thickness was in the range of $3-10 \mu \mathrm{m}$.

The changes of absorption spectra of the films induced by UV (248, 325, and $375 \mathrm{~nm})$ laser light were studied and analysed. The holographic recording of diffraction gratings was performed by different laser lines (325, 442, and $532 \mathrm{~nm})$. During recording the diffraction efficiency was measured simultaneously in transmission and reflection mode. The formation of relief on the film surface was observed and the profile of the gratings was analysed by atomic force microscope. The influence of photoisomerization and photo induced mass transport on the surface-relief formation process has been discussed.

Keywords: arsenic sulphide, Disperse Red 1, spiropyran, polymer-photochrome composite, polymer-photochrome-chalcogenide composite, holographic grating
\end{abstract}

PACS: $78.66 . \mathrm{Sq}$

\section{Introduction}

The thin films of chalcogenides are well known as recording media and widely applicable for a long time in different areas for storing and reproducing information. The selective etching of the films is used very often, too. In this work we propose the chalcogenide materials as a system for direct relief formation under illumination of light without selective etching process.

Recently some publications have been devoted to studies of this process in chalcogenide films, in particular at holographic recording $[1,2]$. The analysis of these works shows that relief formation in the pure chalcogenide films possible at the high value of exposition (approx. $5 \mathrm{~kJ} / \mathrm{cm}^{2}$ and higher). We supposed that direct relief formation would be possible at a lower exposition if the composite material on chalcogenide and polymer base were used. Such materials already have been used for holographic recording [3].

The thin film of composite can be treated as a homogeneous photoresist from the engineering viewpoint and so we can study its absorbtion spectra. But chemically, the composite is a solid dispersion of chalco- genide particles in polymeric matrix. In previous work we have shown the difference in chemical composition of illuminated and non-illuminated areas of the composite [4]. In our opinion, the interaction of electric field and chalcogenide particles leads to mass transport in the films. It is possible that the radiation effect is changing the structure of chalcogenide particles and varies their dipole moment as a result. So the stress and the particles' movement appear in the film.

We assumed that a photoresist of another type with large difference between dipole moment of illuminated and non-illuminated state may activate the mass transport in the composite and thus increase the difraction efficiency of the grating. Organic photochromes can be such additives. Besides, the direct relief formation was observed in the photochrome-polymer films [5, 6].

There are many different types of organic photochromes. Figure 1 shows two types of them and their photoisomerization. Disperse Red 1 (DR1) is azobenzene compound and its mechanism of photoisomerization can be described as cis-trans recombination 


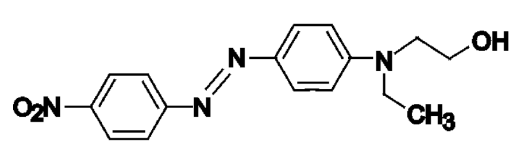

Disperse Red 1 trans

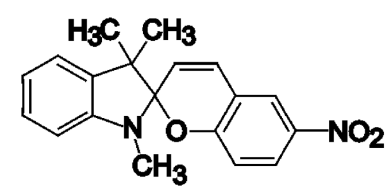

Spiropyran closed
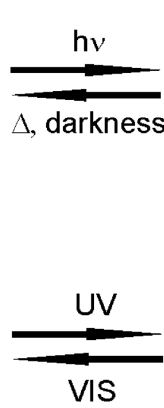

VIS

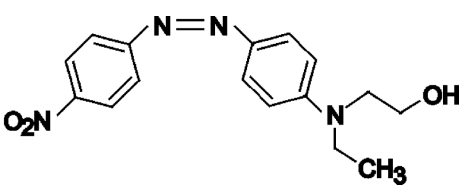

Disperse Red 1 cis

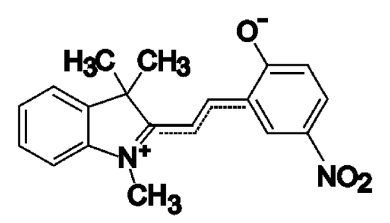

Photomerocyanin open

Fig. 1. Disperse Red 1, spiropyran, and mechanism of their photoisomerization.

relatively to the $\mathrm{N}=\mathrm{N}$ bond. The dipole moments of $\mathrm{cis}$ and trans-form are 6 and 9 D correspondingly [6].

Spiropyran has another photoisomerization mechanism: tautomerization to photomerocyanine form. The dipole moments of spiropyran and photomerocyanine are more different -7.5 and $13.6 \mathrm{D}$ correspondingly [6]. This difference was the reason why we chose the spiropyran as one of the additives for the composite.

\section{Experiment}

There are some problems in preparing the optical homogeneous composites chalcogenide-polymer. Low solubility of chalcogenide in organic solvents and poor compatibility with majority of polymers limits the possibility of production of a wide band of composites. Very often the coagulation of chalcogenide particles takes place at composite film drying and it leads to preparation of composite film with high coefficient of optical scattering. To improve the optical transparency of films the polar copolymer Disperbyk-161 (produced by BYK-Chemie $\mathrm{GmbH}$ ) with free amine groups (an additive for prevention of pigment coagulation) was used. Using this polymer the transparent films of composite with the concentration of $\mathrm{As}_{2} \mathrm{~S}_{3}$ up to $60 \mathrm{wt} \%$ in relation to the polymer were obtained. Originally Disperbyk-161 was planed to be used as a uniform polymer for all composites, but the dry film spiropyranDisperbyk-161 made was not optical homogeneously.

The crushed arsenic sulphide was dissolved in a mixture of organic solvents (N,N-dimetylformamide and diethylamine 9:1 (wt) accordingly). Dissolution took place in a conical retort at interfusion magnetic mixer at room temperature during a few days. $10 \mathrm{wt} \%$ solution of arsenic sulphide was mixed with $30 \mathrm{wt} \%$ solution of polymer Disperbyk-161 (a solvent is mixture of methoxypropylacetate and butylacetate 6:1 (wt) accordingly) in such proportions that after film drying on substrate the mass part of arsenic sulphide was 28,40 , 50 , and $60 \mathrm{wt} \%$.

Disperse Red 1 delivered by Aldrich, CAS 2872-528 was chosen. The powder of DR-1 was dissolved in $\mathrm{N}, \mathrm{N}$-dimetylformamide at room temperature. $10 \mathrm{wt} \%$ solution of DR-1 was mixed with $30 \mathrm{wt} \%$ solution of polymer Disperbyk-161 and with solution Disperbyk$161+\mathrm{As}_{2} \mathrm{~S}_{3}$ in such proportions that after film drying on substrate the mass part components were $5 \mathrm{wt} \%$ DR-1 $+60 \mathrm{wt} \%$ Disperbyk-161 and $5 \mathrm{wt} \%$ DR-1 + $35 \mathrm{wt} \% \mathrm{As}_{2} \mathrm{~S}_{3}+60 \mathrm{wt} \%$ Disperbyk-161 accordingly.

The spiropyran (by Aldrich, CAS 1498-88-0) was dissolved in chloroform at room temperature. A $5 \mathrm{wt} \%$ solution of spiropyran was mixed with poly(vinyl butyral-co-vinyl alcohol-co-vinyl acetate) $M_{\mathrm{w}}=50000$ 80000 (GPC) (CAS 27360-07-2), poly(vinyl acetate) $M_{\mathrm{w}}=500000$ (CAS 9003-20-7), and poly(methyl methacrylate) $M_{\mathrm{w}}=350000$ (CAS 9011-14-7) dissolved in chloroform. The solutions were mixed in such proportion that after drying the mixtures on a substrate the concentration of spiropyran in the polymer would make $5 \mathrm{wt} \%$. Also, to the solution with spiropyran and poly(vinyl acetate) there was added $10 \% \mathrm{As}_{2} \mathrm{~S}_{3}$ solution in organic solvents (as described above), in such a proportion that after drying the mixtures on a substrate the concentration of arsenic sulphide in the composite would be $1 \mathrm{wt} \%$. For studying the transmission spectra of composite in the UV region in more detail, a composition with a $1 \mathrm{wt} \%$ spiropyran concentration in poly(vinyl butyral-co-vinyl alcohol-co-vinyl acetate) was prepared.

Fabrication of films from composites' solutions were performed by company BYK Gardner GmbH applicator, the thickness of liquid layer was $30,60,90$, and $120 \mu \mathrm{m}$. Glass and quartz plates were used as a substrate. For the improvement of moistening the surfactant was added to solution of $\mathrm{As}_{2} \mathrm{~S}_{3}$ and Disperbyk-161 (less than $0.01 \mathrm{wt} \%$ ) before application. The $\mathrm{As}_{2} \mathrm{~S}_{3}$ 
films were dried in oven at a temperature of $303 \mathrm{~K}$ during 30-40 min. The films which contained DR-1 were dried in oven at a temperature of $423 \mathrm{~K}$ during $3 \mathrm{~h}$. The films which contained spiropyran were dried in oven at a temperature of $423 \mathrm{~K}$ for $30 \mathrm{~min}$.

The thickness of dry films was $1.5-9 \mu \mathrm{m}$, determined by the Veeco Dektak 150 surface profiler.

For all films, including the film of pure polymer and pure arsenic sulphide, the spectra of transmission were measured by the Ocean Optic HR4000CG spectrometer. Measurement of pure organic polymer and spiropyran containing films' transmission spectrum was performed with the films on quartz substrate.

The holographic gratings with a period of $\Lambda=1 \mu \mathrm{m}$ were recorded by two symmetrical laser beams of equal intensity with linear horizontal polarization $(\mathrm{p}-\mathrm{p})$. For $\mathrm{As}_{2} \mathrm{~S}_{3}$ and DR1 containing films lasers with wavelength 442 and $532 \mathrm{~nm}$ and beam intensity $0.79-0.86 \mathrm{~W} / \mathrm{cm}^{2}$ were used. The readout of transmission diffraction efficiency was made at the Bragg angle using a semiconductor laser beam of $640 \mathrm{~nm}$ (for recording laser with $442 \mathrm{~nm}$ wavelength) and $673 \mathrm{~nm}$ (for recording laser with $532 \mathrm{~nm}$ wavelength). The second order maximum of recording beam was used for reflection diffraction efficiency measurement.

For spiropyran containing films the holographic gratings with a period of $\Lambda=1 \mu \mathrm{m}$ were recorded by two symmetrical laser beams of equal intensity with linear horizontal polarization $(\mathrm{p}-\mathrm{p})$, using $325 \mathrm{~nm}$ (beam intensity $2 \times 1.8 \cdot 10^{-4} \mathrm{~W} / \mathrm{cm}^{2}$ ) and $532 \mathrm{~nm}$ (beam intensity $2 \times 1.4 \cdot 10^{-3}-2 \times 4.2 \cdot 10^{-2} \mathrm{~W} / \mathrm{cm}^{2}$ ) lasers. The readout of transmission diffraction efficiency was made at Bragg's angle using a $640 \mathrm{~nm}$ semiconductor laser beam (for the $325 \mathrm{~nm}$ recording laser) at the $2 \mathrm{nd}$ order maximum of recording beam (for the $532 \mathrm{~nm}$ recording laser). Immediately before recording by the $532 \mathrm{~nm}$ laser, the samples were illuminated by a $375 \mathrm{~nm}$ laser beam (intensity $0.01 \mathrm{~W} / \mathrm{cm}^{2}$ ) for $5 \mathrm{~min}$.

After recording, the surface relief of the samples was analysed by atomic force microscope (AFM).

For relief formation studying, the films of compositions $5 \mathrm{wt} \%$ DR-1 $+60 \mathrm{wt} \%$ Disperbyk-161 and $5 \mathrm{wt} \%$ DR- $1+35 \mathrm{wt} \% \mathrm{As}_{2} \mathrm{~S}_{3}+60 \mathrm{wt} \%$ Disperbyk-161 were irradiated by cylindrical-lens-focused laser beam with $532 \mathrm{~nm}$ wavelength and intensity of $11 \mathrm{~W} / \mathrm{cm}^{2}$. The focussed light spot linear sizes were $3454 \times 25 \mu \mathrm{m}^{2}$. The profile of irradiated area was studied with a profiler Veeco Dektak 150.

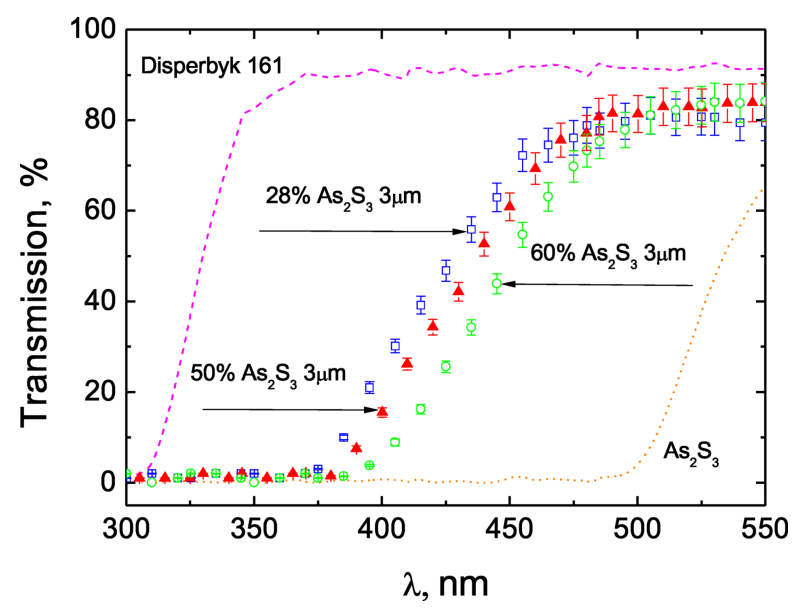

Fig. 2. Dependence of transmission spectra of $\mathrm{As}_{2} \mathrm{~S}_{3} /$ Disperbyk161 composite films on $\mathrm{As}_{2} \mathrm{~S}_{3}$ concentration.

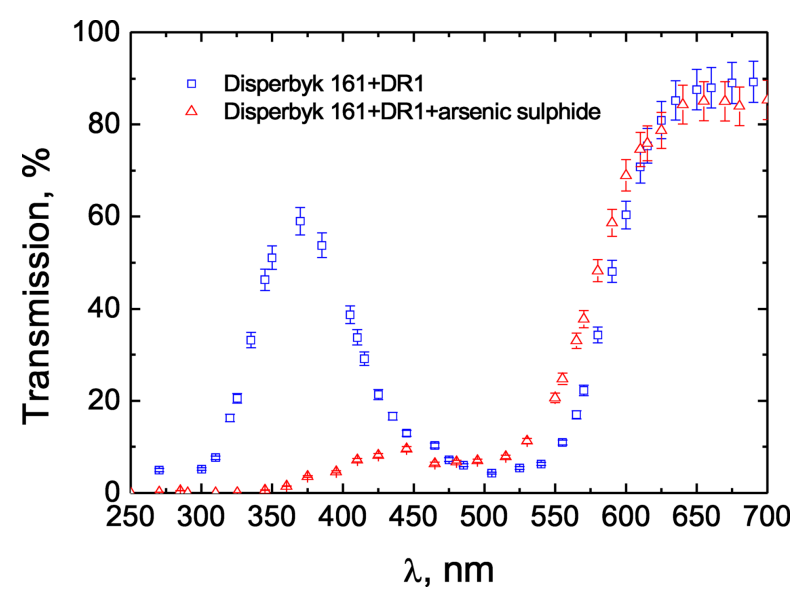

Fig. 3. Dependence of transmission spectra of the composite films on $\mathrm{As}_{2} \mathrm{~S}_{3}$ presence.

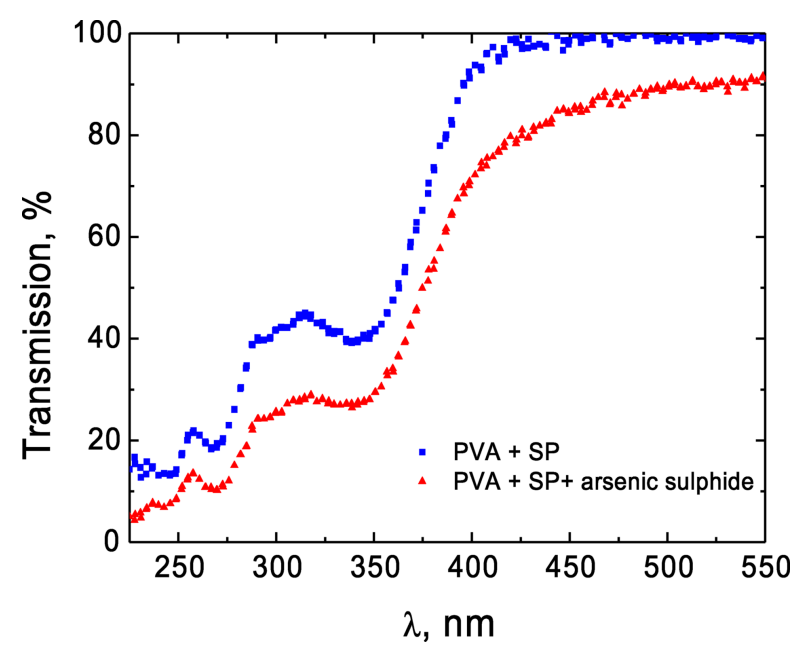

Fig. 4. Dependence of transmission spectra of the composite films on $\mathrm{As}_{2} \mathrm{~S}_{3}$ presence. 


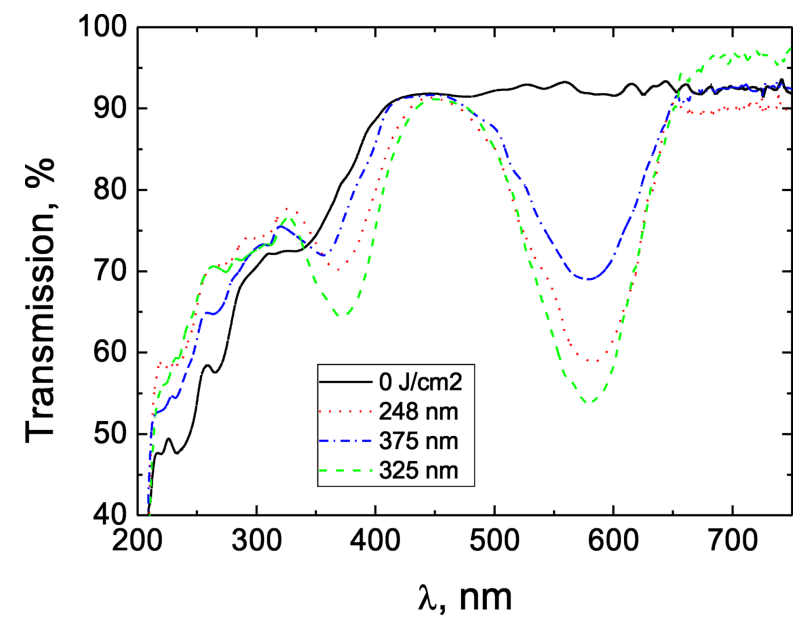

Fig. 5. Transmission spectra of spiropyran-poly(vinyl butyral-covinyl alcohol-co-vinyl acetate) composite before (black line) and after (faltering lines) illumination by different UV-lasers $(E=$ $0.36 \mathrm{~J} / \mathrm{cm}^{2}$ ).

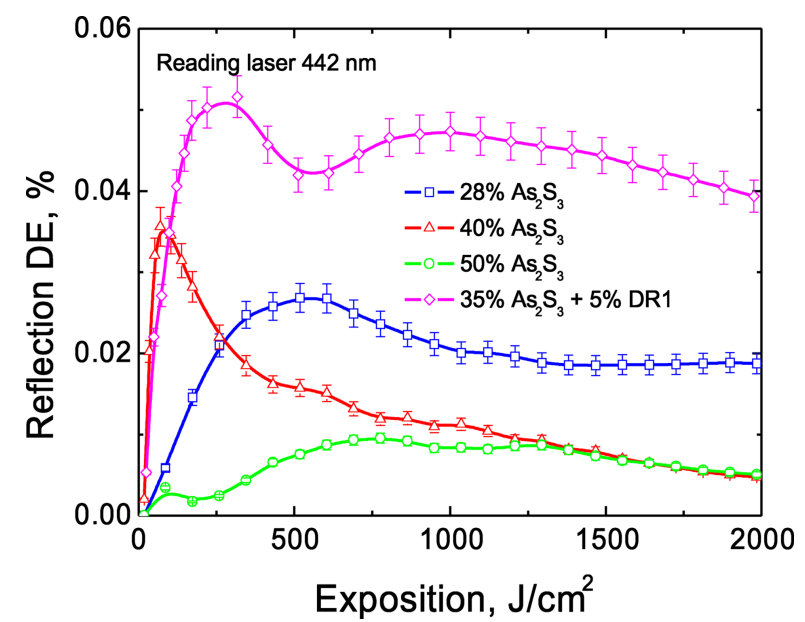

Fig. 6. Reflection (measured at $442 \mathrm{~nm}$ ) diffraction efficiency dependence on recording exposition (recording laser $442 \mathrm{~nm}$ ). Polymeric matrix is Disperbyk-161.

\section{Results and discussion}

Figures 2-4 show transmission spectra of studied compositions: arsenic sulphide / Disperbyk-161, DR1 / arsenic sulphide / Disperbyk-161, and spiropyran / arsenic sulphide/polyvinylacetate. The spectra are displayed so that we can see the influence of components to general transmission spectra of composites. So we could make the composites with set spectral characteristic by changing concentration and ratio of components. Besides, as Fig. 5 shows, the spectra of spiropyran composites are changing under the influence of UV-light (at relatively low value of exposition $-0.36 \mathrm{~J} / \mathrm{cm}^{2}$ ) due to transition to photomerocyanine form. This transition occurs most intensively at illumination of poly(vinyl

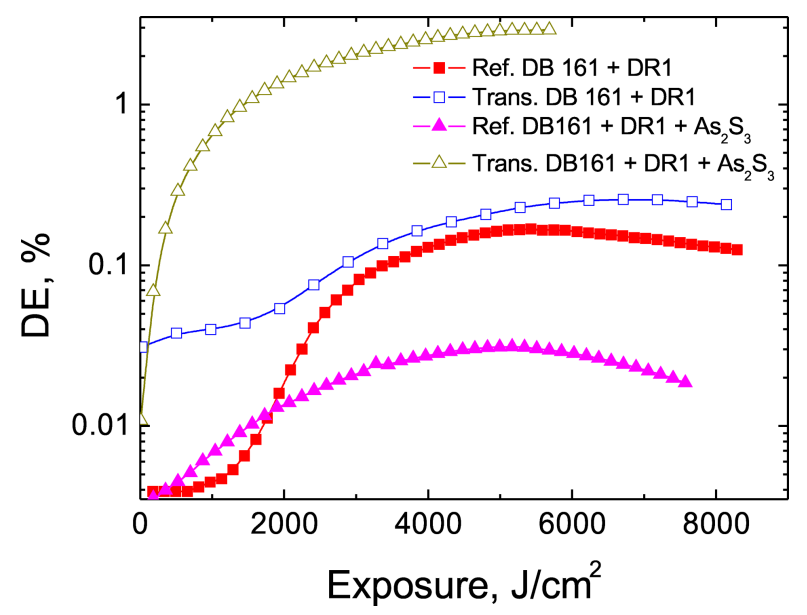

Fig. 7. Transmission (measured at $640 \mathrm{~nm}$ ) and reflection (measured at $532 \mathrm{~nm}$ ) diffraction efficiency dependence on recording exposition (recording laser $532 \mathrm{~nm}$ ). Polymeric matrix is Disperbyk-161.

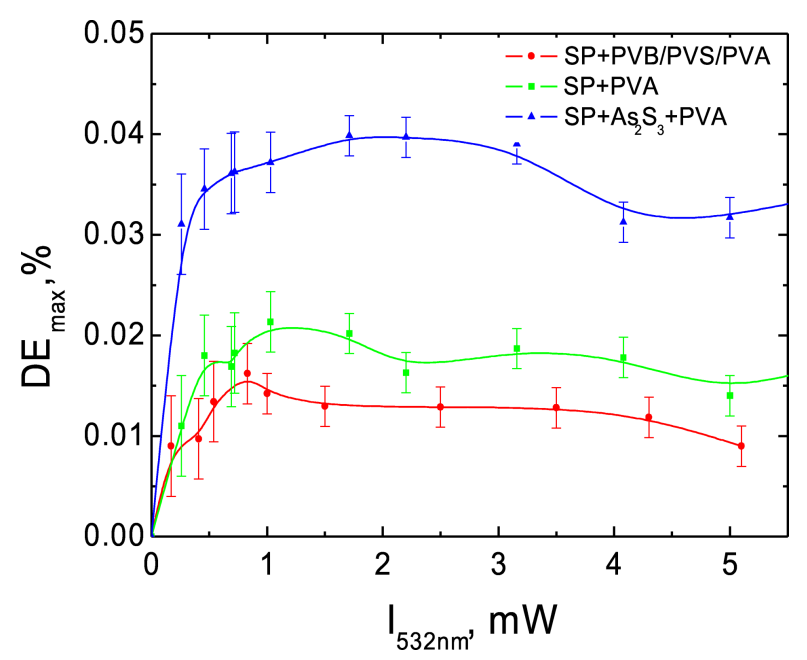

Fig. 8. Dependence of transmission diffraction efficiency maxima on the recording beam intensity (recording and reading lasers $532 \mathrm{~nm})$.

butyral-co-vinyl alcohol-co-vinyl acetate) / spiropyran film by $325 \mathrm{~nm}$ laser.

The results of holographic recording in composites, namely, difraction efficiency dependence on exposure can be seen at Figs. 6 and 7. From these graphs it is obvious that the presence of arsenic sulphide and DR1 together in the composite increases the difraction efficiency in comparison with materials containing only one photoresist. Approximately the same picture can be seen in the composite film spiropyran/arsenic sulphide in PVA (Fig. 8). In this case we tried to record the grating in photomerocyanine form, a more detailed description was published in [7]. Figure 8 shows the dependence of maxima of difraction efficiency on record- 
ing beam intensity. The top curve corresponds to composite spiropyran / arsenic sulphide in PVA.

A very important question is how does the grating form in the composite films. We assumed that the particles of chalcogenide situated at a maximum recombine in another amorphous modification, as shown, for example, in [8]. At the same time, photochrome particles recombine to another isomerization form. The polymer molecules usually do not change at wavelength longer than $350-400 \mathrm{~nm}$.

Structural modifications in photoresists lead to thermodynamic imbalance in composite film. If viscosity and polarity of the polymer allow the movement of photochrome and chalcogenide particles, the composite film structure orders according to the bands of minimum and maximum. It does not mean that a relief formation takes place, though; it is possible that the movement of polymer macromolecules is required for it.

Figure $9(a, b)$ demonstrates the character of surface relief dependence on contents of composite. The presence of just arsenic sulphide gives "the hole" but the presence of DR1 and arsenic sulphide gives "the hill". The dependence of relief height on exposure for composite $5 \mathrm{wt} \%$ DR-1 $+35 \mathrm{wt} \% \mathrm{As}_{2} \mathrm{~S}_{3}+60 \mathrm{wt} \%$ Disperbyk-161 can be seen at Fig. 9(c). We made an experiment with two different directions of electric field vector (changing the beam polarization), but it insignificantly influenced the height of relief. The exposure of order of $5 \mathrm{~kJ} / \mathrm{cm}^{2}$ is required for reaching a height of relief of about $100 \mathrm{~nm}$ (this is a usual height of relief that can be obtained at selective etching of chalcogenide film [9]). The maximum height of relief may be 600 $800 \mathrm{~nm}$ at exposure of $25 \mathrm{~kJ} / \mathrm{cm}^{2}$.

Unfortunately, in spiropyran containing composites we did not receive direct surface relief. The reason for this can be that the spiropyran photoisomerization takes place at very low exposure (under $2-4 \mathrm{~mJ} / \mathrm{cm}^{2}$ ) [7]. At exposure higher than $50-100 \mathrm{~J} / \mathrm{cm}^{2}$ the spiropyran containing composites lost photoisomerization properties, possibly because of chemical decomposition. This situation confirms our assumption that the photoresist dipole moment change is not enough for direct relief formation in the composites; the movement or restructuring of polymer macromolecules is required for it.

Figure 10 shows AFM images of relief gratings obtained without selective etching operation.

\section{Conclusions}

The composite material on the basis of arsenic sulphide, DR-1, and copolymer Disperbyk-161 with differ-
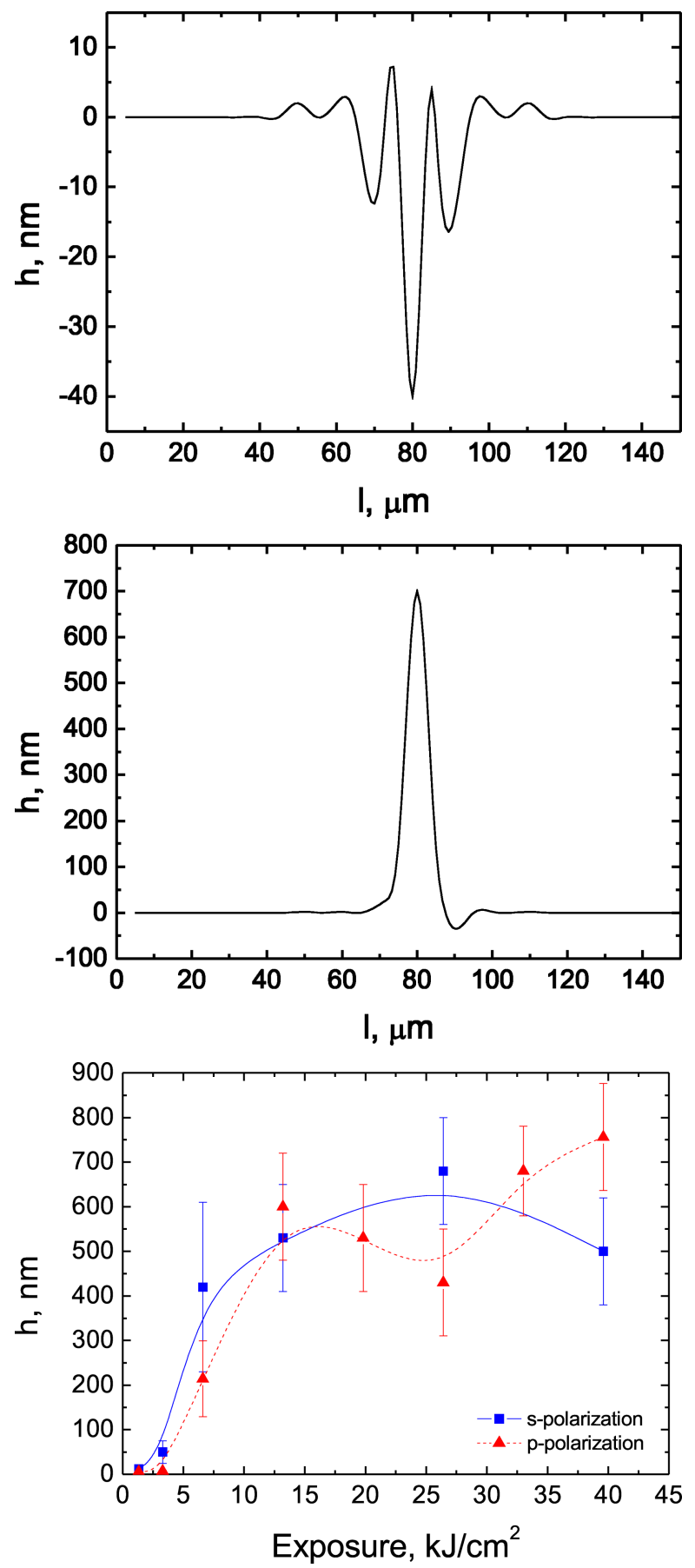

Fig. 9. Character of the relief after laser irradiation of composites through cylindrical lens by a laser beam of $532 \mathrm{~nm}$ : (a) profiles of relief of composition $40 \mathrm{wt} \% \mathrm{As}_{2} \mathrm{~S}_{3}+60 \mathrm{wt} \%$ Disperbyk-161, (b) profiles of relief of composition $5 \mathrm{wt} \% \mathrm{DR} 1+35 \mathrm{wt} \% \mathrm{As}_{2} \mathrm{~S}_{3}+$ $60 \mathrm{wt} \%$ Disperbyk-161, (c) height of relief dependence on exposure for the composite $5 \mathrm{wt} \% \mathrm{DR}-1+35 \mathrm{wt} \% \mathrm{As}_{2} \mathrm{~S}_{3}+60 \mathrm{wt} \%$ Disperbyk-161.

ent proportion of components and low optical scattering was obtained. The composite with addition of Disperse Red 1 has a higher value of transmission diffraction efficiency of gratings. The direct surface relief formation 


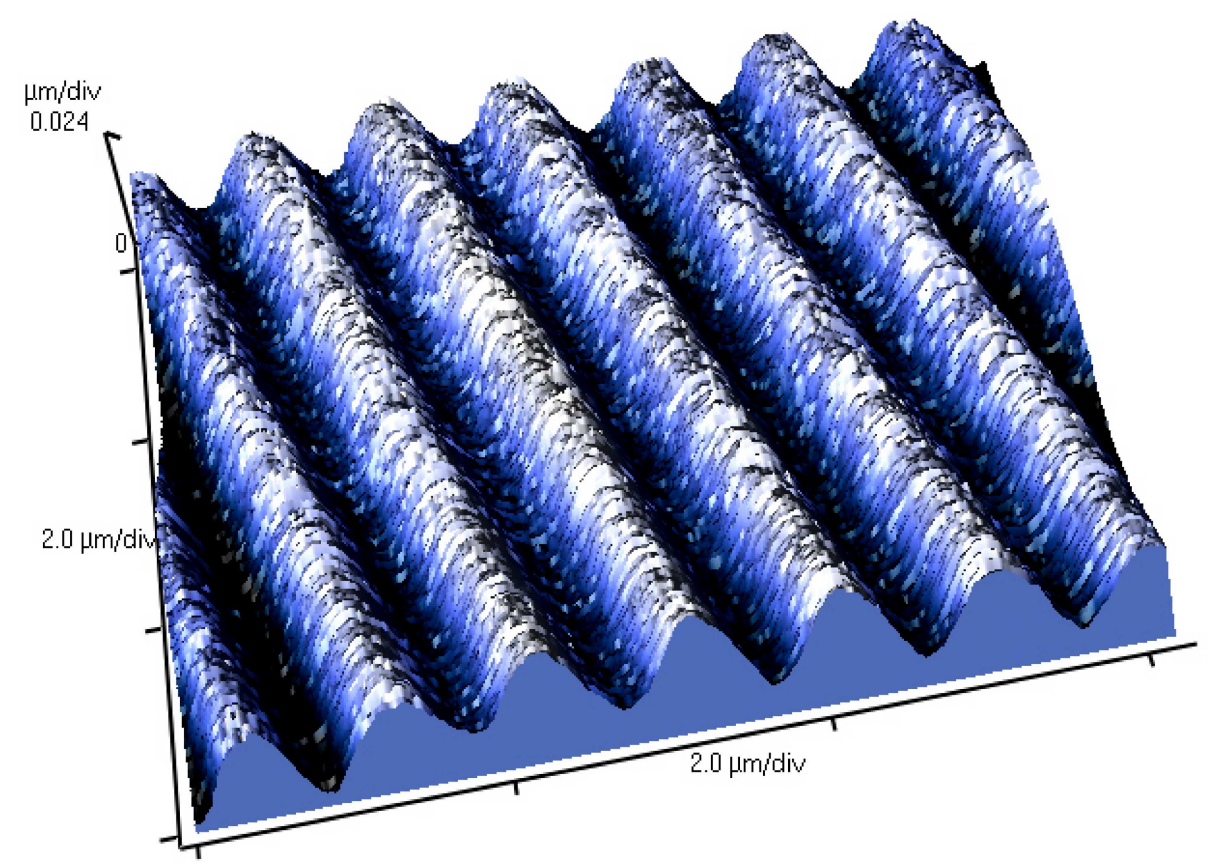

(a)

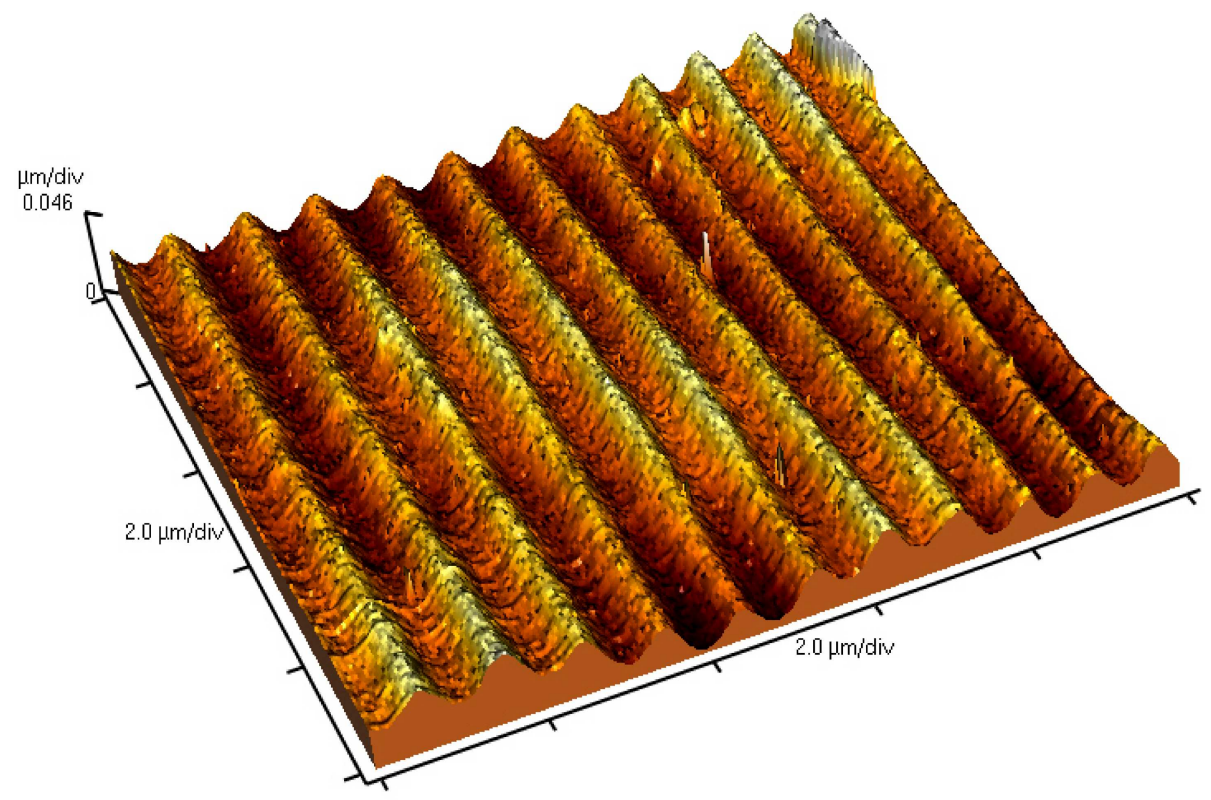

(b)

Fig. 10. AFM images of surface relief holographic grating recorded by $532 \mathrm{~nm}$ laser in composites (a) $40 \mathrm{wt} \% \mathrm{As}_{2} \mathrm{~S}_{3}+60 \mathrm{wt} \%$ Disperbyk161 and (b) $5 \mathrm{wt} \% \mathrm{DR}-1+35 \mathrm{wt} \% \mathrm{As}_{2} \mathrm{~S}_{3}+60 \mathrm{wt} \%$ Disperbyk-161; film thickness $\sim 5 \mu \mathrm{m}$.

by holographic recording in the composites has been shown.

Also we have obtained composites with various concentration of spiropyran, with and without presence of arsenic sulphide in various polymers: polyvinylacetate, polymethylmetacrylate, and copolymer of poly(vinyl butyral-co-vinyl alcohol-co-vinyl acetate).

The studies of the initial transmission spectra of composites and their changes induced by lasers of wavelengths of 248, 325, and $375 \mathrm{~nm}$ revealed an appearance of absorption band in the spectral region of $475-650 \mathrm{~nm}$ with a maximum at $580 \mathrm{~nm}$. The holographic recording of transmission gratings was performed. It was shown that diffraction efficiency increases in the presence of arsenic sulfide.

So the composites with combination of arsenic sul- 
phide and photochromes are more effective for difraction recording.

The hypothesis of mechanism of direct relief formation in the composites was discussed.

\section{References}

[1] U. Gertners and J. Teteris, Direct holographic recording on amorphous chalcogenide films, in: 22nd International Conference on Amorphous and Nanocrystalline Semiconductors (ICANS22), Colorado, USA, 19-24 August 2007, abstract ThP13.7.

[2] U. Gertners and J. Teteris, Latvian J. Phys. Tech. Sci. 3, 30-36 (2009).

[3] A. Andries, V. Bivol, A. Prisacar, S. Sergheev, A. Me- shalkin, S. Robu, N. Barba, and N. Sirbu, J. Optoelectron. Adv. Mater. 7, 1169-1178 (2005).

[4] A. Gerbreders, J. Teteris, and V. Kolobjonoks, Proc. SPIE 7142, 714212 (2008).

[5] C. Cojocariu and P. Rochon, Pure Appl. Chem. 76, 1479-1497 (2004).

[6] Y. Atassi, J. Chauvin, J.A. Delaire, J.-F. Delouis, I. Fanton-Maltey, and K. Nakatani, Pure Appl. Chem. 70, 2157-2166 (1998).

[7] A. Gerbreders, J. Teteris, J. Aleksejeva, and A. Danilovs, Latvian J. Phys. Tech. Sci. 3, 23-29 (2009).

[8] G.A. Bordovsky, S.A. Nemov, N.I. Anisimova, I.A. Dzemidko, A.V. Marchenko, and P.P. Seregin, Semiconductors 43, 352-354 (2009).

[9] A. Gerbreders and J. Teteris, J. Optoelectron. Adv. Mater. 9, 3164-3166 (2007).

\title{
HOLOGRAFINIS IૃRAŠYMAS FOTOCHROMO-CHALKOGENIDO KOMPOZITUOSE
}

\author{
A. Gerbreders ${ }^{\mathrm{a}, \mathrm{b}}$, J. Aleksejeva ${ }^{\mathrm{a}}$, A. Danilovs ${ }^{\mathrm{a}}$, J. Teteris ${ }^{\mathrm{a}}$ \\ ${ }^{a}$ Latvijos universiteto Kietojo kūno fizikos institutas, Ryga, Latvija \\ ${ }^{\mathrm{b}}$ Daugpilio universitetas, Daugpilis, Latvija
}

\begin{abstract}
Santrauka
Aprašytas metodas plonoms trigubo kompozito, sudaryto iš organinio polimero, chalkogenido ir fotochromo, plèvelèms gaminti. Kartu ištirtas tokių plèvelių optiniu savybių kitimas veikiant šviesai ir jų panaudojimas holografiniam įrašymui. Kompozito plèvelès gautos iš arseno sulfido, organiniu polimerų, tokių kaip „Disperbyk“ (gaminamas BYK Chemie $\mathrm{GmbH}$ ), ir polivinilacetato tirpalu organiniuose tirpikliuose. Papildomai i ši mišini buvo pridedama azobenzeno dispersinio raudonojo dažiklio (DR-1) ir spiropirano tirpalų. Plèvelès pagamintos liejant šią medžiagą ant stiklo ar
\end{abstract}

kvarco pagrindo. Sausos plèvelès storis siekė $1-3 \mu \mathrm{m}$. Tirti ir analizuoti plèvelių sugerties spektrų pokyčiai, sukeliami UV $(248,325$ ir $375 \mathrm{~nm}$ ) lazerinès spinduliuotès. Skirtingo bangos ilgio (325, 442 ir $532 \mathrm{~nm}$ ) lazerio spinduliuote holografiškai įrašinètos difrakcinès gardelès. Irašo metu matuotas vienalaikis perejusiosios ir atspindètosios šviesos difrakcinis efektyvumas. Reljefo susiformavimas plèvelès paviršiuje stebètas ir gardelių profilis analizuotas atominès jègos mikroskopu. Aptarta fotoizomerizacijos ir šviesos sukeliamos masès pernašos itaka paviršinio reljefo formavimuisi. 